\title{
Praktyczny konstytucjonalizm federalisty Publiusa i jego filozoficzne podstawy
}

\author{
Marta Dubowska \\ Uniwersytet Jagielloński w Krakowie \\ m.dubowska@gmail.com \\ Otrzymano 12 grudnia 2017, zaakceptowano 21 stycznia 2018, opublikowano 26 kwietnia 2018.
}

\begin{abstract}
Abstrakt
The Federalist Papers, mimo iż napisane w 1787 roku, są nadal jedną z najczęściej przywoływanych prac dotyczących problemów konstytucyjnych. Eseje Hamiltona, Madisona i Jaya, ukrywających się pod pseudonimem „Publius”, są szeroko cytowane, jednak nie zawsze w zgodzie z intencjami ich autorów. Artykuł ten ma na celu: po pierwsze, zarysować historyczne i polityczne tło, na jakim powstawały eseje, aby podkreślić ich umiejscowienie w konkretnej epoce; a po drugie, zdekonstruować filozoficzną podstawę esejów, jednocześnie wykazując, jak pomijanie takiej podstawy może doprowadzić do wypaczenia zamierzonej przez autorów argumentacji.
\end{abstract}

Słowa kluczowe: federaliści; konstytucja; filozofia prawa; Publius; Hume; Locke.

\section{Wstęp}

W niniejszym artykule przedstawię filozoficznoprawne aspekty federalizmu, do których odwołuje się najsłynniejszy federalista w historii nowożytnej myśli politycznej - wyimaginowany autor Publius, pod którego pseudonimem kryją się trzej Ojcowie Założyciele Stanów Zjednoczonych, to jest A. Hamilton, J. Madison i J. Jay. Twórczość Publiusa jest często cytowana $\mathrm{w}$ amerykańskim dyskursie politycznym, a na treści podnoszone w esejach składających się na The Federalist Papers (Hamilton, Madison, Jay, 2015) powołują się co rusz najważniejsi współcześni politycy republikańscy (gdy argumentują za silną pozycją rządu federalnego, nieograniczonym prezydenckim prawem łaski oraz gdy postulują powrót do historycznych form protekcjonizmu i merkantylizmu), a także protestujący przeciwko nadużyciom władzy federalnej prawnicy i dziennikarze. Można wręcz mówić o istnieniu w amerykańskim dyskursie politycznym „Argumentu z Federalisty Publiusa”, 
który jest szczególnym rodzajem argumentu z autorytetu. Niestety, argumentu nazbyt często - szczególnie przez polityków - nadużywanego (a nadużycia tego rodzaju mogą prowadzić do przypisania Publiusowi argumentów w postaci „topornych” konstrukcji filozoficznych, których faktycznie nigdy nie przedstawiał).

W tym krótkim tekście nie będę analizować systematycznie treści esejów Publiusa i ograniczę się do wskazania ogólnych praktycznych implikacji filozofii polityczno-prawnej, której hołdował. Myśl ta do dziś uchodzi za najlepszą obronę i wykładnię obowiązującej od ponad dwóch wieków Konstytucji Stanów Zjednoczonych. Zanim jednak przejdę do meritum, dla lepszej orientacji czytelnika opiszę realia polityczno-prawne kształtujące potrzebę, która doprowadziła do powstania The Federalist Papers. Wierzę przy tym, że ujawnienie przyczyn powstania samego tego dzieła, jak i praktycznej filozofii, opartej przede wszystkim na fundamentalnych założeniach filozofii J. Locke'a i D. Hume'a, samo będzie zachętą do podwyższenia (głównie wśród polityków) standardów argumentacyjnych w debatach konstytucyjnych. Jak sądzę, The Federalist Papers, stanowiąc wzór tego, jak należy argumentować na rzecz reformy konstytucyjnej, stanowią lekturę obowiązkową dla wszystkich, którzy pragną rzeczowo dyskutować o reformie polskiej Konstytucji z 1997 roku, z politykami na czele (treści przekazywane przez Publiusa mają bowiem charakter ponadczasowy).

\section{Realia historyczne}

Uchwalenie Konstytucji Stanów Zjednoczonych podczas II Kongresu Kontynentalnego w Filadelfii w maju 1787 roku było wydarzeniem tyle znaczącym, co niespodziewanym. Kongres ten został bowiem pierwotnie zwołany po to, aby częściowo zrewidować anachroniczną, pochodzącą z 1777 roku konstytucję, tak zwane „Artykuły konfederacji i wieczystej unii"'. Ten ostatni akt, określający pierwotne zasady ustrojowe funkcjonowania Stanów Zjednoczonych Ameryki, w bardzo szeroki sposób wyznaczał zakres suwerenności wszystkich stanów (podówczas trzynastu). W czasie wojny o niepodległość, a więc do 1783 roku, względna niezależność stanów rodziła niejednokrotnie problemy, o mały włos nie doprowadzając do przegrania wojny. Artykuły przekazywały centralną władzę jednoizbowemu Kongresowi, złożonemu z przedstawicieli stanów, przy czym każdy stan - niezależnie od wielkości i liczby ludności - dysponował jednym głosem. Kongres prowadził politykę zagraniczną, miał prawo wypowiadania i prowadzenia wojny, sprawował kontrolę nad armią i flotą, a także sprawował rolę sądu arbitrażowego między stanami, gdy te popadały w spory. Utrzymywał pocztę i emitował pieniądz, którego wartość ustalał. Jednakże, co kluczowe, Artykuły nie powoływały organów władzy wykonawczej oraz władzy sądowniczej, pozostawiając te kwestie w rękach poszczególnych stanów. W szczególności Kongres nie miał prawa nakładać podatków, nie mógł regulować handlu międzystanowego i zagranicznego, a także nie posiadał żadnych narzędzi egzekwowania swoich decyzji. W praktyce uzależniało to skuteczność decyzji Kongresu od dobrej woli władz

\footnotetext{
${ }^{1}$ Krótkie wprowadzenie historyczne oparto zasadniczo na Osiatyńskim (1977). Choć są to kwestie powszechnie znane, krótkie ich przypomnienie wydaje się pomocne.
} 
poszczególnych stanów. Podobnie utrzymanie armii, które wymagało niemałych przecież środków, zależne było od dostarczania przez stany środków, prowiantu oraz żołnierzy, a ze zobowiązań tych stany nierzadko po prostu się nie wywiązywały. Ten „niedostatek” władzy wykonawczej, rodzący poważne komplikacje w trakcie wojny, stanowił także realny problem po jej zakończeniu. Choć zdawano sobie sprawę z konieczności reform, to władze stanowe, pomne niedawnych ograniczeń suwerenności przez władze angielskie, z wielkimi oporami podchodziły do pomysłu jakiejkolwiek radykalnej reformy. Tymczasem powojenne problemy (głównie związane z koniecznością wypłaty zaległego żołdu), jak i panujący w niektórych stanach ogólnie pojęty chaos, wymagały podjęcia jednoznacznych i jednolitych w skali kraju działań. Kongres Kontynentalny miał pierwotnie dokonać jedynie częściowej rewizji Artykułów. Dopiero w toku prac Kongresu, głównie pod wpływem argumentów J. Madisona, A. Hamiltona i T. Paine’a, plany „częściowej rewizji” Artykułów przekształciły się w zupełnie nowy projekt Konstytucji. Jak wskazuje W. Osiatyński, za całkowitą zmianą ustroju państwa opowiadała się nowa elita amerykańska, która uświadamiała sobie szczególną wspólnotę interesów (co jednak nie znaczy, że poza partykularnym interesem tej elity nie istniało ogólnofilozoficzne uzasadnienie postulatów proponowanych przez nich reform). Cytując:

Elitę tę stanowili bogaci kupcy, bankierzy, właściciele przedsiębiorstw, spekulanci ziemią, właściciele papierów wartościowych oraz skryptów długu państwowego zaciągniętego podczas wojny i wreszcie oficerowie posiadający skrypty na wypłatę należnego żołdu. Pragnęli oni wypłaty długów w wartościowej monecie, a nie w zdewaluowanym pieniądzu papierowym. Domagali się więc utworzenia ogólnonarodowego banku, który zająłby się wykupem obligacji. Wszyscy przedstawiciele grup elitarnych pragnęli przywrócenia w kraju ładu i porządku oraz stworzenia warunków do rozwoju przemysłu i handlu międzystanowego, a także międzynarodowego. Uważali oni, że warunki takie może stworzyć tylko silny rząd centralny, który by zabezpieczył jednocześnie interesy najbogatszych grup społeczeństwa. Udzielili więc chętnie poparcia ruchowi na rzecz rewizji „Artykułów konfederacji” i zmiany charakteru Unii. (Osiatyński, 1977, s. 40-41)

Nowa Konstytucja wprowadzała silną władzę wykonawczą w postaci urzędu prezydenta oraz jego silne prerogatywy (na przykład prawo względnego weta w stosunku do ustaw Kongresu), lecz wbrew założeniom A. Hamiltona (który postulował, wzorując się na ideach monarchicznych, jego dożywotni charakter), organowi temu nadano charakter kadencyjny; olbrzymie uprawnienia zostały jednak ograniczone przez możliwość przeprowadzenia impeachmentu, czyli postawienia prezydenta w stan oskarżenia przed Senatem (jako sądem) za zdradę, przekupstwo i inne zbrodnie. Sądownictwo oparto na koncepcji supremacji prawa federalnego nad stanowym. Przeciwwagą dla silnej egzekutywy miał być natomiast dwuizbowy parlament (Kongres), w którego izbie wyższej (Senacie) stany miały być reprezentowane zgodnie z zasadą równości, a w izbie niższej (Izbie Reprezentantów) z zasadą proporcjonalności: rozwiązanie to miało umożliwiać koalicji mniejszych stanów zablokowanie niekorzystnych dla nich rozwiązań proponowanych przez większe stany w izbie niższej; z kolei wprowadzenie odmiennej kadencyjności izb miało zagwarantować ciągłość władzy, umożliwiając zmienność jej organów; Kongres uzyskał uprawnienia do nakładania podatków, regulacji handlu, emisji pieniądza itd. Nadanie rządowi 
federalnemu szerokich uprawnień nastąpiło w postaci enumeratywnego ich wyliczenia. Wprowadzenie w tej kwestii numerus clausus miało sugerować, że suwerenna władza spoczywa w rękach stanów, które dobrowolnie zrzekają się jej części (w zakresie wyznaczonym przez katalog zamknięty). W tej części rząd centralny (federalny) mógł bezpośrednio oddziaływać na obywateli we wszystkich stanach.

Zmiany te były na tyle radykalne, że praktycznie niemożliwe było ich wiążące uchwalenie - delegaci na Kongres uznali, że nie mają uprawnień dla w pełni wiążącego ich przyjęcia. Konwencja postanowiła zatem, że warunkiem wejścia Konstytucji będzie jej ratyfikacja przez co najmniej dziesięć parlamentów stanowych.

To właśnie to ostatnie postanowienie zbliża nas już bardzo blisko do okoliczności, w których powstawał Federalista ${ }^{2}$. Proces ratyfikacji Konstytucji od początku przebiegał bowiem w warunkach ostrego konfliktu między federalistami - czyli zwolennikami nowej Konstytucji - a antyfederalistami, którzy krytykowali wprowadzany przez nią centralizm władzy, uznając go za zagrożenie dla wolności i suwerenności stanów. Spór między federalistami i antyfederalistami był w zasadzie sporem o to, w jaki sposób realizować republikańskie ideały. W obronie „federalistycznej” wizji zjednoczyli swe siły mający nieco zróżnicowane poglądy A. Hamilton (republikanizm arystokratycznomonarchiczny) i J. Madison (tradycyjny republikanizm) oraz J. Jay. Łączyło ich przekonanie, obce antyfederalistom, że legitymacja silnego rządu centralnego pochodzi bezpośrednio od obywateli (antyfederaliści uznawali natomiast, że legitymacja ta pochodzi od stanów, które posiadają szczególną, quasi-państwową formę suwerenności).

\section{The Federalist Papers}

Od października 1787 do marca 1788 Jay, Madison i Hamilton napisali w sumie 85 esejów, w których bronili nowych rozwiązań konstytucyjnych. Posługiwali się przy tym niejednokrotnie wysublimowanymi argumentami filozoficznymi (pochodzącymi od Locke'a czy Hume'a), lecz stronili od nudnego języka filozofii prawa i filozofii politycznej, mogącego raczej zrazić niż zachęcić przeciętnego czytelnika. Poważne argumenty filozoficzne były więc przez narratora Publiusa przemycane w postaci argumentacji „zdroworozsądkowej”, której jednak nie można było odmówić walorów literackich. Publius odwoływał się przy tym do ugruntowanych w myśli anglosaskiej idei prawa naturalnego (przekonania o istnieniu obiektywnego systemu nakazów moralnych) i konstytucjonalizmu (przekonania o tym, że konstytucja stanowi najlepsze zabezpieczenie przeciwko rządom tyrańskim), a także powszechnego wśród Amerykanów poczucia cnoty obywatelskiej (obejmującej między innymi patriotyzm, służbę publiczną, przedsiębiorczość, oszczędność, żądanie sprawiedliwości, a także - szczególnie po wojnie o niepodległość - samorządność).

\footnotetext{
${ }^{2}$ Zamiennie stosuję nazwę polską i dwie angielskie, pełną i skrótową, mianowicie: Federalista, The Federalist Papers oraz The Federalist.
} 
Podnoszone przez Publiusa argumenty od początku uznawane były za czysto ,praktyczne"3. Taką opinię wyrażał między innymi T. Jefferson, gdy w maju 1790 roku w liście do przyjaciela, T. M. Randolpha, Jr. pisał, że w jego własnej bibliografii najważniejszych dzieł z zakresu filozofii politycznej znajdują się The Wealth of Nations A. Smitha (który to tekst uznawał za najlepszą książkę z zakresu ekonomii politycznej), De l'esprit des lois Monteskiusza (który to traktat „ogólnie polecał”, choć zalecał też uważną lekturę z uwagi na to, że jest on mimo wszystko „miksturą prawd i omyłek”) oraz „mały traktat o rządzie” (mając na myśli Second Treatise of Government J. Locke'a, który uznawał za „idealny w każdym calu”). Dopiero na samym końcu bibliografii, po wskazanych dziełach, znalazło się The Federalist Papers, wraz z oceną, którą należy przytoczyć w całości. Jefferson napisał: „Schodząc z poziomu teorii do poziomu praktyki nie ma lepszej książki nad Federalistę" (Jefferson, 1950; tłumaczenie moje) ${ }^{4}$.

Ocenę taką, mającą na celu dyskredytację The Federalist, należy jednak uznać za przesadną. Jak podkreśliłam wyżej, choć Publius realizuje w swej argumentacji zasadniczo cel praktyczny (chce bowiem przekonać do ratyfikacji Konstytucji), to czyni to poprzez - co prawda ciche - odwołanie się do silnych argumentów filozoficznych, z których czytelnik powinien sobie zdawać sprawę. Publius postrzega swoje zadanie obrony Konstytucji za zadanie z zakresu nauk politycznych. Sama nauka polityczna była rozumiana przez niego jako nauka deskryptywna zajmująca się identyfikowaniem i opisywaniem takich zagadnień jak: powstawanie fakcji (klik społecznych, grup interesów), konsekwencje posiadania wielkiej republiki (które były porównywane z konsekwencjami posiadania małej republiki), a także mniej abstrakcyjnych i bardziej praktycznych kwestii takich jak: kwestia tego, jakie cele zrealizuje wprowadzenie podziału władz, zasady checks and balances czy podziału sądownictwa na sądownictwo federalne i stanowe. Większość tych rozważań jest przy tym bezpośrednio oparta na poglądach dotyczących natury ludzkiej. The Federalist Papers nie są więc wyłączne entuzjastycznym komentarzem dla pewnej regulacji konstytucyjnej czy po prostu zbiorem rozpraw z zakresu prawa konstytucyjnego. Wywody Publiusa na temat rozdziału władz (niezależności sądownictwa, dwuizbowego parlamentu, którego konstrukcja sprzyja realizacji interesów zarówno dużych, jak i małych stanów) czy choćby metod poboru podatków obfitują w argumenty teoretyczne. Faktycznie, „eseistyczno-pamfletowa” formuła z pewnością nie pozwala uznać The Federalist za

\footnotetext{
${ }^{3}$ Jak wskazuje W. Osiatyński, myśl ta była rzeczywiście umotywowana potrzebami praktycznymi. Jak pisze: „W dobie amerykańskiej rewolucji umysłowej nie powstał ani jeden traktat zawierający wizję systemu społeczno-politycznego na miarę Arystotelesa, Tomasza z Akwinu czy Locke'a. Nie o teoretyzowanie bowiem chodziło ówczesnym twórcom, ale o realizację konkretnych, uchwytnych celów politycznych. Autorami nie byli gabinetowi uczeni, lecz praktycy - przywódcy ruchu niepodległościowego, twórcy nowych instytucji politycznych. W pisaniu często byli amatorami, nie dbali o specjalnie wyszukane konstrukcje myślowe czy stylistyczne, ale o jak najprostsze przekonanie czytelnika do swoich argumentów, a dokładniej - o pozyskanie go do swoich celów" (Osiatyński, 1977, s. 8). Nie było to jednak równoznaczne z brakiem myśli filozoficznej u podstaw argumentacji Federalisty.

${ }^{4}$ „D e s c e n d i n g from theory to practice there is no better book than the Federalist” (Jefferson, 1950; wyróżnienie moje).
} 
traktat filozoficzny. Jednakże gdyby opierać się na tak określonych kryteriach „dzieła teoretycznego” czy „filozoficznego”, nie można by za takowe uznać wielu dialogów Platona, co byłoby przecież absurdem.

Jak wskazuje autor dwóch książek poświęconych filozoficznym podstawom myśli ojców rewolucji amerykańskiej, Morton G. White (Philosophy of the American Revolution, 1978; Philosophy, The Federalist, and the Constitiution, 1987), broniący Konstytucji Publius odwołuje się do takich pojęć jak ,niezbywalne prawo”, „,natura człowieka” czy „oczywista prawda” (self-evident truth), które zostały ugruntowane pod wpływem filozofii prawa natury Locke'a, Hume'a i Burlamaqui'ego (dziś nieco zapomnianego szwajcarskiego prawnika), a także w pewnym stopniu pod wpływem myśli Arystotelesa, Cycerona, św. Tomasza z Akwinu, Hookera, Hobbesa, Grocjusza, Pufendorfa, Wolfa, Vattela czy Hutchesona (znajomość ich dzieł była wśród ludzi wykształconych w owym czasie powszechna). M. White nazywa zresztą tych filozofów, którzy w zasadniczej mierze ukształtowali myślenie Ojców Założycieli, „Praojcami Założycielami” (founding forefathers). Ten sam autor wskazuje jednak także, że zasadnicze znaczenie dla uformowania myśli Publiusa mieli D. Hume i J. Locke (White, 1978, 1987). Wagę przedstawianych niejako „W przebraniu” argumentów filozoficznych podkreśla natomiast antyczna stylizacja esejów (Publius jako narrator).

Filozoficzne podstawy „praktycznej” argumentacji Publiusa wymagają podkreślenia, bowiem ich ujawnienie zadaje kłam podniesionemu w 1913 roku przez C. Bearda twierdzeniu, że Konstytucja amerykańska była dziełem kierującej się własnym wąskim interesem ekonomicznym elity (Beard, 1968). Wskazanie na uniwersalne podstawy filozoficzne pozwala uchylić tego rodzaju argument, który przypomina też te używane aktualnie, przez przeciwników obecnej polskiej Konstytucji (uznawanej bezrefleksyjnie za dziecko niedookreślonej ekonomiczno-politycznej ,grupy interesów”).

Poniżej ograniczę się do przedstawienia dwóch najpoważniejszych teoretycznych założeń argumentacji Publiusa - w zakresie w jakim opiera się ona na argumentacji Locke’a i Hume'a. Co ciekawe, choć w wielu punktach filozofia tych dwóch ojców brytyjskiego empiryzmu jest zgodna, to czasami radykalnie się różni: w wielu kwestiach Hume pozostawał radykalnym empirystą (co zresztą było przyczyną późniejszego szacunku, jakim obdarzał jego argumentację XIX wieczny empirysta J. S. Mill), zaś Locke, starający się między innymi obiektywnie uprawomocnić wiarę w Boga i zasady moralne, był w tych kwestiach bardziej zachowawczy, gotów dokonywać nieraz dalece idących ustępstw na rzecz racjonalizmu (co było zresztą przyczyną krytyk, jakie pod adresem filozofii Locke’a kierował Hume). W The Federalist Papers znajdujemy niejednokrotnie mieszankę tych dwóch filozofii. Choć współgrają one ze sobą w wielu punktach (w takim wypadku inspirowana nimi argumentacja Publiusa pozostaje spójna), to w sytuacjach, gdy wspomniani dwaj filozofowie wygłaszają odmienne opinie, argumentacja Publiusa przyjmuje co najmniej eklektyczny bądź „hybrydowy” charakter (przy czym eklektyzm ten nie wiąże się bynajmniej z tym, że The Federalist to dzieło wieloautorskie, gdyż niespójności pojawiają się także w esejach pisanych przez tego samego autora). 
Pojęcia rozumu (reason), doświadczenia (experience), oczywistej prawdy (self-evident truth), pierwotnej prawdy (primary truth), nieodłącznego prawa (unalienable right), historii (history) czy w ogóle pojęcie prawa naturalnego to pojęcia obciążone ogromnym bagażem filozoficznym. Tymczasem Publius używa ich tak, jakby były to pojęcia zupełnie oczywiste, niewymagające opowiedzenia się po którejś ze stron odwiecznego sporu między empiryzmem i racjonalizmem. Krótka refleksja nad wpływem filozofii Hume’a i Locke'a na myśl Publiusa pozwala dojść do przekonania, że każda tego rodzaju, roszcząca sobie ,praktyczny” charakter argumentacja polityczno-prawna, jest trudna do zrozumienia (interpretacji) bez znajomości jej głębszych podstaw filozoficznych. Pozostaje natomiast w pełni przekonująca jedynie dla tych, którzy uznają wyżej wskazane pojęcia, podążając za sugestią praktycznie nastawionego Publiusa, za oczywiste.

\section{Przyczajony Hume}

Pod nazwą „widelec Hume'a” znane jest opisane przez tego filozofa odróżnienie prawd rozumowych (,demonstratywnych”, dotyczących „związków idei”) i prawd eksperymentalnych (dotyczących kwestii „faktów lub istnienia”). Empiryzm Hume wymagał jednak, aby wbrew utartym poglądom uznawać wszelkie prawdy, poza prawdami matematycznymi, za prawdy u swych podstaw empiryczne. Uznawał on także, że filozofia polityczna jest nauką empiryczną. W An Enquiry Concerning Human Understanding (Hume, 1748) pisał on, że każde rozumowanie rzekomo „czyste” („refleksyjne”) ostatecznie kończy się przywołaniem zasad lub argumentów, które są uzasadnione przy pomocy obserwacji i doświadczenia. Hume odróżniał przy tym dwa rodzaje argumentów empirycznych: takie, które zostały sformułowane przy pomocy rożnych form rozumowania (w których na przykład tak zwane ,aksjomaty” pochodzą ostatecznie z doświadczenia), oraz takie, które mają charakter stwierdzeń opartych na bezpośrednim doświadczeniu. Przykład ilustrujący ogólną tezę Hume'a pochodzi zresztą z historii politycznej starożytnego Rzymu:

The history of a TIBERIUS or a NERO makes us dread a like tyranny, were our monarchs freed from the restraints of laws and senates: But the observation of any fraud or cruelty in private life is sufficient, with the aid of a little thought, to give us the same apprehension; while it serves as an instance of the general corruption of human nature, and shows us the danger which we must incur by reposing an entire confidence in mankind. In both cases, it is experience which is ultimately the foundation of our inference and conclusion (Hume, 1748, Section V, przypis 7, akapit 4; wyróżnienia moje).

W ten sposób wskazał Hume na dwa różne rodzaje argumentów, które mogą prowadzić do wyprowadzenia wniosku, że władcy (monarchowie) zwolnieni ze wszystkich ograniczeń konstytucyjnych stają się tyranami: argumenty historyczne (będące argumentami z bezpośredniego doświadczenia) oraz nieco bardziej złożone argumenty ogólne, wymagające przeprowadzenia bardziej skomplikowanego rozumowania (dokonania obserwacji zachowań ludzi w pewnych okolicznościach, szczególnie takich, gdy posiadają nieograniczone możliwości działania; wyciągnięcia ogólnych wniosków - to jest dokonania odpowiednich generalizacji - na temat natury ludzkiej; i na koniec wyprowadzenia z nich 
szczególnych twierdzeń na temat działania monarchów w takich okolicznościach). Jak łatwo zauważyć, pierwszy rodzaj argumentu (historycznego) wymaga posiadania pewnych konkretnych doświadczeń (faktów na temat monarchów, takich jak Tyberiusz i Neron). Natomiast drugi rodzaj argumentu nie wymaga, aby monarchowie w ogóle kiedykolwiek istnieli - rozumowanie takie przeprowadza się bowiem w oparciu o spostrzeżenia dotyczące zachowań ludzi, niekoniecznie monarchów. Argumentacja Hume’a, że dowody w naukach polity c zny ch nie tylko opierają się na bezpośrednich faktach (argumenty praktyczne), ale także na rozumowaniach z pewnych prawideł natury ludzkiej (argumenty teoretyczne), odgrywa istotną rolę w wielu miejscach w argumentacji federalisty Publiusa. Autorzy The Federalist trzymali się Hume’owskiego założenia, że teoria polityczna jest teorią empiryczną i odwoływali się zarówno do szeroko pojętego doświadczenia pozwalającego opisać prawidła zachowania się wszystkich ludzi, jak i węziej pojętego doświadczenia pozwalającego opisać, jak zachowują się poszczególni ludzie w szczególnych okolicznościach, a także doświadczenia dotyczącego przeszłych pojedynczych wydarzeń oraz doświadczenia dotyczącego teraźniejszych pojedynczych wydarzeń. Podobnie jak Hume uznawali, że historia zajmuje się pojedynczymi, szczegółowymi faktami, podczas gdy nauka polityczna zajmuje się faktami ogólnymi.

Przemawiający wspólnym głosem Jaya, Madisona i Hamiltona Publius zasadniczo jest więc empirystą, który broni przeważającej części swoich przekonań poprzez odwołanie się do doświadczenia w taki sposób, co do którego Hume nie miałby (metodologicznych, epistemologicznych) zastrzeżeń. Różne formy rozumowania eksperymentalnego, o których pisze Hume niejednokrotnie, są przez Publiusa stosowane do uzasadniania jednego i tego samego przekonania (tym samym nabiera ono zarówno teoretycznego, jak i praktycznego charakteru).

Jeden z takich przykładów znajdujemy w Eseju 10 (autorstwa Madisona, zresztą jednym z najsłynniejszych - z uwagi właśnie na ten argument), gdzie Publius przedstawia swoją teorię fakcji (przedstawiając ich ,jakości, przyczyny i skutki”) i wskazuje, że przyczyną istnienia fakcji jest nierówna dystrybucja dóbr. Nie jest to jednak przyczyna jedyna (stąd błędne byłyby jakiekolwiek skojarzenia z marksizmem), bowiem Publius wprost wskazuje, że przyczynami tworzenia się fakcji są także nieuniknione różnice opinii oraz odmienność charakterów. Argumentuje on, że faktycznie nie da się usunąć fakcji - posiadanie przez ludzi takich samych interesów, opinii i pasji byłoby bowiem niemożliwe. Argumentacja ta opiera się zasadniczo na zbiorze pewnych maksym czy prawidłowości na temat ludzkiej natury, które nie wymagają przedstawiania szczegółowych badań i obserwacji, bowiem są oczywiste nawet dla młodzika. Z tego powodu Publius-Madison nie musi przedstawiać szczegółowej listy przykładów (faktów) potwierdzających to, że ludzie różnią się co do zdolności pozyskiwania dóbr i gromadzenia majątku; że to rząd powinien ich chronić, tak, aby mogli wykorzystywać w pełni swe odmienne zdolności; że w sytuacjach, gdy będą realizować te zdolności, różne rodzaje dóbr zostaną wytworzone w społeczeństwie; że, wreszcie, realizacja tych zdolności doprowadzi do tego, że wytworzą się w społeczeństwie różne grupy interesów lub fakcje ekonomiczne, składające się z ludzi mających odmienne poglądy i uczucia. Prezentując te argumenty, Publius zakłada, że 
każdy zgodzi się z nim - w oparciu o swoje własne uogólnione obserwacje, że istotnie to różnice ekonomiczne stanowią najpowszechniejszą i najbardziej trwałą przyczynę istnienia fakcji społecznych. Podobne podejście znajdujemy także w napisanym przez Hamiltona Eseju 6, w którym ten stwierdza, że ci, którzy dysponują przyzwoitą wiedzą o naturze ludzkiej nie potrzebują - dla przeprowadzenia rozumowania i wyprowadzenia wniosku, że istnienie fakcji społecznych jest koniecznością - bardziej szczegółowych przykładów.

Jest jasne, że autorzy esejów nie angażowali w argumentacji metody demonstratywnej (badającą związki idei, czysto rozumowej) tak, jak ją pojmował Hume, bo The Federalist Papers nie był traktatem z zakresu matematyki, lecz teorii politycznej i prawnej. Problematyczne są jednak $z$ tego punktu widzenia te fragmenty (głównie autorstwa Hamiltona), w których uznaje on przeprowadzane przez siebie dowody za „czysto rozumowe” bądź podobne dowodom matematycznym. W tych fragmentach ujawnia się bliższy raczej Locke'owi niż Hume'owi - racjonalizm.

\section{Ukryty Locke}

Jak wskazałam, filozofia Hume’a była w znacznej mierze inspiracją dla autorów The Federalist. Autorzy tego dzieła dobrze ją znali i zasadniczo akceptowali jej kluczowe założenia metodologiczne i epistemologiczne. W kilku kwestiach jednak dokonali wyraźnego odstępstwa od tych założeń. Z całą pewnością Publius nie podziela etycznej konsekwencji filozofii Hume'a, zgodnie z którą każdy sąd na temat cnoty moralnej, zła moralnego (wyrażający etyczną ocenę czyjegoś zachowania) może być uznany za oddający własne emocje moralne (sentiments) oceniającego. Ten subiektywistyczny pogląd na naturę ocen etycznych wyraził Hume w Enquiry Concerning the Principles of Morals (Appendix I), pisząc między innymi, że moralność, jako związana z celami ludzkich działań, jest określana przez uczucia i sentymenty (1751). Można zaryzykować stwierdzenie, że na gruncie etyki Hume'owskiej każde pytanie o to, czy dany rodzaj czynu jest moralnie dobry, czy zły, jest, jak zauważył XX-wieczny filozof C. D. Broad, pytaniem z zakresu statystyki. W Federaliście natomiast nie ma śladu takiego „konwencjonalistycznego” podejścia do etyki. Jak pisze M. White, tego rodzaju pogląd był dla Madisona przekleństwem, bowiem wierzył on, że dane działanie może być obiektywnie ocenione jako niemoralne lub niesprawiedliwe, nawet jeżeli większość w społeczeństwie uważa lub odczuwa inaczej (w szczególności: uznaje dany rodzaj działania za pożądany lub nawet - przyjemny; White, 1987, s. 85-91). Podobne zdanie wyrażał Hamilton, który nawet w ostatnim, 85 Eseju, wprost odciął się od teorii Hume'a (Hamilton pisze o nim jako o wielkim i godnym szacunku filozofie, z którym akurat w tej kwestii się nie zgadza).

Z powyższych względów warto w tym miejscu przedstawić teorię moralną J. Locke’a, która jest teorią obiektywistyczną i racjonalistyczną (pomimo faktu, że Locke był empirystą). To właśnie ta teoria stanowi filozoficzną podstawę wielu twierdzeń i ocen moralnych wygłaszanych przez Publiusa. Locke wierzył bowiem, że nauka moralna może być „,nauką demonstratywną" - tak samo jak matematyka. Aby jednak możliwe było wyprowadzanie 
twierdzeń moralnych na sposób „matematyczny”, konieczne jest przede wszystkim przedstawienie zbioru moralnych aksjomatów. Aksjomatami tymi miałyby być „oczywiste prawdy moralne", które zawierałyby między innymi doktrynę praw naturalnych. Każdy taki aksjomat moralny byłby „oczywisty” (self-evident) w tym sensie, że każdy, kto by go usłyszał, natychmiast by się z nim zgodził, o ile tylko rozumiałby znaczenie pojęć, które zostały użyte do jego sformułowania. W An Essay Concerning Human Understanding Locke (1689) pisał, że podstawową zdolnością poznawczą (umysłu) pozwalającą ludziom odkrywać aksjomaty moralne jest intuicja. Federalista jest przesiąknięty ideą, że pewne twierdzenia moralne są obiektywne i oczywiste dla każdego, kto potrafi posługiwać się rozumem - w tym sensie jest to zdecydowanie Locke'owska teoria. Intuicja stanowi przy tym główną postawę twierdzeń składających się na doktrynę prawa naturalnego.

Zarówno w Eseju 2 (Jay), jak i Eseju 43 (Madison) - gdzie dyskutowane są potrzeba powołania rządu i cele, jakie rząd ma realizować - odwołanie się do idei praw naturalnych jest niezwykle skrótowe, podobne zresztą do tego, jakie znajdujemy w Deklaracji niepodległości (a jej autor, Jefferson, znajdował się pod wielkim wpływem filozofii politycznej Locke'a). Z kolei w Eseju 51 Publius (Madison) wskazuje, że w społeczeństwie, w którym zawsze silniejsza fakcja może wywrzeć presję na słabszej fakcji, z konieczności będzie panować anarchia, co pozostaje w bezpośrednim związku z twierdzeniem Locke'a na temat stanu natury, w którym silniejszy ma zawsze możliwość poskromić słabszego. Jednakże Publius-Madison argumentuje, podobnie jak Locke (1689, rozdział 9, par. 123), że silniejsze indywidua, powodowane niepewnością co do własnych warunków egzystencji, poddają się dobrowolnie woli rządu, który ochrania zarówno słabych, jak i ich - faktycznie silniejszych. Czynnik niepewności powoduje zatem, że nawet de facto silniejszy woli zrezygnować z części swego potencjału i poddać się opiece rządu. Silne fakcje społeczne będą zatem zawsze skłonne wspierać budowę wielkiej republiki, która - w interesie wszystkich fakcji, słabych i silnych - będzie broniła je przed agresją ze strony innych. Interes własny fakcji prowadzi więc tutaj - tak jak w przypadku Locke’owskiego interesu indywidualnego - do stworzenia pewnych nadrzędnych instytucji, które są w interesie wspólnym wszystkich obywateli (fakcji).

W słynnym Eseju 10 o fakcjach Publius-Madison argumentuje natomiast, że społeczeństwo, w którym prawa naturalne nie są zabezpieczone i w którym może zawsze wygrać silniejsza fakcja, nie jest społeczeństwem sprawiedliwym. Uznaje zatem, podobnie jak Locke, że stan natury jest stanem ,nieetycznym”, w którym dominuje „diabelski interes fakcyjny”. Dodawał tam, że ,transcendentalne prawa natury” i „Bóg obecny w naturze” określiły zabezpieczenie podstawowych praw jednostki i ochronę dobra wspólnego (public good) za podstawowe powinności społeczeństwa. Nie daje on tam jednak żadnych dokładniejszych wyjaśnień co do natury tych praw, najwyraźniej uznając - ponownie w duchu Locke'a - że są to sądy intuicyjne i oczywiste. 
Wskazane odwołania do Locke'owskiej idei intuicyjnego prawa naturalnego prowadziły także - podobnie jak w pisanej przez T. Jeffersona Deklaracji niepodległości - do uzasadnienia idei oporu wobec tyranii. W Eseju 28 Publius-Hamilton stwierdza, że jeśli reprezentanci ludu sprzeniewierzają się tym najbardziej podstawowym zasadom w swych zgromadzeniach, to nie pozostaje nic innego jak tylko „wyegzekwować te oryginalne uprawnienia osobiście w drodze samoobrony, która przeważa nad każdą pozytywną formą rządu". Trzeba jednak zauważyć, że prawo to - podobnie jak w Deklaracji niepodległości - przysługiwało nie w obliczu jakichkolwiek nadużyć władzy prowadzących do częściowego zakwestionowania praw naturalnych (bo w takim wypadku lojalność wobec władzy ciągle była przez te prawa pośrednio uzasadniona i pozostawała cnotą nadrzędną), ale w przypadku - jak to określił Madison w Eseju 43 - ,absolutnej, moralnej konieczności”.

Ponadto, jak zaznaczyłam już nieco wyżej, w co najmniej kilku miejscach Hamilton sugeruje, że w oparciu o podobne aksjomaty, stosując metodę demonstratywną, jest on w stanie wyprowadzić pewne niepodważalne prawdy z zakresu nauk politycznych - dotyczące jakichś faktów politycznych (twierdzenie to Hume uznałby za herezję).

Jak widać, Publius często uciekał się do dowodów demonstracyjnych i intuicyjnych w dziedzinach, w których Hume uznawał to za niedopuszczalne - w teorii polityki i moralności. Wsparciem dla takiego postępowania mogła być tylko filozofia Locke’a.

\section{Podsumowanie}

Lektura The Federalist Papers nakazuje, szczególnie w przypadku argumentów prawnych (choć zapewne należy taki wniosek uogólnić także na inne dziedziny argumentacji), zapytywać: jaka teoria filozoficzna (między innymi epistemologiczna czy etyczna) stoi u ich podstaw i czy jesteśmy skłonni zgodzić się z tymi argumentami, gdy już ją poznamy. Jak sądzę, praktyczna filozofia prawa Publiusa uczy nas wiele; wymaga jednak od nas jeszcze więcej - aby zrozumieć sens uregulowań konstytucyjnych, musimy poznać ich głębsze uzasadnienie filozoficzne. Próba interpretacji i krytyki tych esejów ujawnia bowiem, że każdy, kto chce odpowiedzialnie dyskutować o rozwiązaniach ustrojowych, powinien zgłębić tradycję filozoficzną, z której się one wywodzą, nawet jeśli nie jest ona powierzchownie dostrzegalna. I to jest właściwe przesłanie, które Publius - przy pomocy swego „praktycznego" języka - kieruje do wszystkich zaangażowanych w sprawy reformy konstytucyjnej w dowolnym czasie i kraju świata. A więc także w Polsce ostatnich kilku lat.

\section{Bibliografia}

Beard, C. (1968). An economic interpretation of the Constitution of the United States. New York, NY: Macmillan.

Hamilton, A., Madison, J., Jay, J. (2015). The federalist papers. (J. Miller, red.). Mineola, NY: Dover Publications. 
Hume, D. (1748). An enquiry concerning human understanding. Pobrano 2016 z: https://ebooks.adelaide.edu.au/h/hume/david/h92e/

Hume, D. (1751). Enquiry concerning the principle of morals. Pobrano z: https://www.gutenberg.org/files/4320/4320-h/4320-h.htm

Jefferson, T. (1950). The papers of Thomas Jefferson (Tom XVI). (J. Boyd, red.). Princeton, NJ: Princeton University Press.

Locke, J. (1689). An essay concerning human understanding. Pobrano z: http://enlightenment.supersaturated.com/johnlocke/BOOKIVChapterII.html

Locke, J. (1689). Second treatise of government. Pobrano z: http://www.earlymoderntexts.com/assets/pdfs/locke1689a.pdf

Osiatyński, W. (1977). Narodziny Stanów Zjednoczonych. W: W. Osiatyński (red.), Wizje Stanów Zjednoczonych w pismach Ojców Założycieli (A. Jarczewski, Tłum.). Warszawa: Państwowy Instytut Wydawniczy.

White, M. (1978). The philosophy of American Revolution. New York, NY: Oxford University Press.

White, M. (1987). Philosophy, The Federalist, and the Constitution. Oxford, UK: Oxford University Press.

\title{
The Practical Constitutionalism of the Federalist (Publius) and Its Philosophical Foundations
}

\begin{abstract}
The Federalist Papers, even though written in 1787, are still one of the most referenced works regarding constitutional matters nowadays. The words of Hamilton, Madison and Jay, disguised under the pseudonym of Publius, are widely quoted, unfortunately not always in accordance with the authors' intentions. This paper aims to: firstly, sketch the historical and political background of the essays to establish their existence as a period piece, and secondly, deconstruct the philosophical basis of the essays and at the same time show how ignoring such a basis can lead to distortion of the arguments originally intended.
\end{abstract} Keywords: federalist; constitution; philosophy of law; Publius; Hume; Locke. 